\title{
Expression of e-cadherin in early mouse embryo development
}

\author{
Duygu MUTLUAY ${ }^{1, a^{*}}$ \\ ${ }^{I}$ Mehmet Akif Ersoy University, Faculty of Veterinary Medicine, Department of Histology and Embryology, Burdur, Turkey \\ ORCID: 0000-0003-3286-130X ${ }^{a}$
}

\section{MAKALE BILGISI:}

ARTICLE

INFORMATION:

Geliş / Received:

18 Haziran 2019

18 June 2019

Kabul / Accepted:

03 Eylül 2019

03 September 2019

Anahtar Sözcükler:

E-kadherin

Embryo gelişimi

Fare

Hücre adezyonu

Preimplantasyon

Keywords:

Cell adhesion

E-cadherin

Embryo development

Mouse

Preimplantation

\begin{abstract}
:
E-cadherin is a member of the cadherin superfamily of calcium-dependent cell adhesion molecules, and has critical roles in cell adhesion during early embryo development. To determine the expression and distribution of E-cadherin, we applied immunofluorescent staining on late 8 cell, morula and blastocyst stage embryos during the experiments. Firstly, we superovulated the female mice and sacrificed them to isolate oviducts. We flushed 2 cell embryos by using FHM HEPES-buffered medium from the CD1 female mouse oviducts and cultured them in KSOM medium until the blastocyst stage. Embryos were fixed and immunostained with E-cadherin, then images were assessed using a fluorescence microscope. We demonstrate that E-cadherin is expressed throughout the late 8 cell to fully expanded blastocysts. We observed that E-cadherin is present only in the cell-cell contact sites and not in the apical sites of the membrane of late 8 cell stage embryo. In morula, E-cadherin localized on the surface of blastomeres and cell-cell junctions. In blastocyst stage, embryos showed membrane staining in cell-cell contact regions in trophectoderm cells while localized on the surface of inner cell mass. Our results indicate that E-cadherin mediated cell adhesion has important roles on compaction, trophectoderm epithelial differentiation and implantation.
\end{abstract}

\section{Farelerde erken embriyo gelişiminde e-kadherin ekspresyonu \\ ÖZET:}

Kalsiyum bağımlı hücre adezyon moleküllerinden kadherin üst ailesinin bir üyesi olan E-kadherin'in erken embriyonik gelişim sırasında hücre adezyonunda kritik rolleri vardır. E-kadherin ekspresyonunu ve dağılımını belirlemek için, geç 8 hücre, morula ve blastosist aşamalarında bulunan embriyolara immünofloresan boyama uygulandı. İlk olarak dişi farelere superovulasyon uyguladıktan sonra sakrifiye edilerek oviduktar izole edildi. CD1 dişi farelerin oviduktları FHM HEPES-tamponlu medyum ile yıkanarak 2 hücreli embriyo elde edildi ve istenilen embriyo aşamalarında kullanılmak üzere KSOM medyumu içerisinde blastosist aşamasına kadar kültüre edildi. Embriyolar tespit edildi ve Ekadherin ile immun boyama yapıldıktan sonra, floresan mikroskobu kullanılarak görüntüler çekildi ve değerlendirildi. E-kadherinin geç 8 hücreli aşamadan tamamen genişletilmiş blastosist aşamaları boyunca eksprese edildiği gösterildi. Geç 8 hücreli embriyoda E-kadherin, membranın apikal bölgelerinde yer almazken sadece hücre-hücre temas bölgelerinde var olduğu gözlemlendi. Morulada E-kadherin, blastomerlerin yüzeyinde ve hücre-hücre birleşim alanlarında lokalize olduğu görüldü. Blastosist aşamasındaki embriyolarda, ICM'nin yüzeyinde lokalize olurken, TE hücrelerinde hücre-hücre temas bölgelerinde membran boyaması olduğu da gösterilmiştir. Sonuçlarımız, E-cadherin kaynaklı hücre adezyonunun, kompaksiyon, trofektoderm epitelyal farklılaşması ve implantasyon sürecinde önemli rollere sahip olduğunu göstermektedir.

How to cite this article: Mutluay D: Expression of e-cadherin in early mouse embryo development. Veteriner Hekimler Dernegi Dergisi, 91(1): 9-14, 2020, DOI: 10.33188/vetheder.579594

\footnotetext{
* Sorumlu yazar e-posta adresi/ Corresponding author e-mail address: duygumutluay@gmail.com
} 


\section{Introduction}

Cell adhesion molecules have a fundamental importance in early mouse embryo because of their roles in mediating cell-cell interactions during subsequent development (Fleming TP, 2001). E-cadherin is the first identified cell adhesion molecule of the catenin family. These calcium dependent cell adhesion molecules play a central role in generation and maintenance of epithelial cell polarity adhesion. E-cadherin is distributed in the adherens junctions, especially lateral side of the epithelial plasma membrane, and extracellular domain of E-cadherin allows it to be expressed on neighboring cells (14).

E-cadherin has a major role on the adhesion of blastomeres during preimplantation mammalian embryo development (14). Preimplantation embryonic development of mouse extends from fertilization to implantation of the embryo and its attachment to the uterine wall. Following the fusion of sperm with oocyte, the zygote undergoes mitotic cell divisions, resulting in the formation of 2 cell, 4 cell, 8 cell, morula and blastocyst stage embryos, respectively. In the 8-cell stage, embryo has morphologically identical blastomeres until compaction. During compaction, blastomeres become closely apposed like a ball of cells whose cell borders are not distinguishable anymore (6). Compaction process is mediated primarily by E-cadherin molecules while vezatin and nectin-2 adhesion also exist at that time (2). Blastomeres also undergo apical-basal polarization with compaction. As a result of compaction, adherens junctions form at the cell-to-cell contact sites, forming the embryo called morula. After the generation of morula, small cavities form and expand to create one big cavity, from now on the embryo is called blastocyst. The blastocyst consists of two cell lineages called trophectoderm (TE) and the inner cell mass (ICM). The TE is a single outer layer of polarized epithelial cells which mediates the implantation of the embryo and contributes to placentation, while ICM is composed of pluripotent unpolarized cells that give rise to the fetus (13). E-cadherin is necessary for the formation of trophectoderm epithelium that is critical for implantation and attachment of the embryo to endometrium. By the E4.5 (embryonic day 4.5) blastocyst (fully expanded blastocyst) stage, ICM cells are segregated into two distinct cell layers called primitive endoderm $(\mathrm{PrE})$ and pluripotent epiblast (Epi) that gives rise to visceral and parietal endoderm and most of the cells of the embryo proper respectively (7).

In the current study, we aimed to determine the expression and distribution of E-cadherin molecule in mouse early embryo development. Understanding the expressions and functions of these molecules during early development is essential for people and animals to maintain a successful pregnancy.

\section{Material and Methods}

\section{Animals:}

Female $(\mathrm{n}=10)$ and male $(\mathrm{n}=10)$ CD1 mice were purchased from Mehmet Akif Ersoy University Experimental Animal Breeding Unit. Animals were kept in 12h light:12h dark cycle with unlimited access to water and food. This research was approved by the Veterinary Faculty Experimentation Ethics Committee of Mehmet Akif Ersoy University (Ethics Committee Certificate no: 511/2019).

\section{Collection of embryos:}

CD1 female mice 8-10 weeks of age were induced to superovulate by intraperitoneally injections of 5 IU of equine chorionic gonadotropin (PMSG) and human chorionic gonadotropin (hCG) at 48 hours (h) apart. Female mice were mated overnight with fertile males. Following morning, inseminated females were selected by the presence of vaginal plug. Selected females were sacrificed by cervical dislocation and two cell stage embryos ( $\mathrm{n}=60)$ were flushed from the dissected oviducts with FHM HEPES-buffered medium (Millipore-Sigma) at 44-46 h after hCG injection. After that, embryos were cultured in $20 \mu 1$ drops of KSOM medium (Millipore-Sigma) under mineral oil at $37^{\circ} \mathrm{C}$ in a $5 \% \mathrm{CO}_{2}$ humidified air incubator until 8 cell, morula, E 3.5 and E4.5 cell stage for the following experiments (8). 


\section{Fixation and Immunofluorescent Staining}

Embryos were fixed in 4\% paraformaldehyde solution in phosphate-buffered saline (PBS) for 25 min at room temperature. Embryos were subsequently permeabilized in PBS containing $0.5 \%$ Triton X-100 for 15 min and blocked with 5\% bovine serum albumin in PBS containing 0.1\% Tween-20. After blocking, samples were incubated in the primary antibody overnight at $4{ }^{\circ} \mathrm{C}$ and were incubated in secondary antibody for $2-3 \mathrm{~h}$ at $25^{\circ} \mathrm{C}$. The primary antibody provided was, rabbit anti-E-cadherin (Santa Cruz) and secondary antibodies used were conjugated with Alexa Fluor 546 (Life Technologies) namely goat anti-rabbit and conjugated with Alexa Fluor 488 (Life Technologies), namely donkey anti-rabbit. Actin filaments were visualized by adding phalloidin conjugated with Alexa 546 in the secondary antibody solution to visualize cell membranes. Stained samples were mounted in ProLong Gold antifade reagent containing 4', $6^{\prime}$-diamidino-2-phenylindole (DAPI; Thermo Fisher Scientific) on a slide (8). Negative and positive control staining on different stage of embryos were done and the specificity of the E-cadherin secondary antibody was determined that no E-cadherin staining was observed in negative control groups.

\section{Microscopy and Image Analysis}

Different stages of embryos were assessed and imaged using BX51 (Olympus) fluorescence microscope.

\section{Results}

The expression of E-cadherin was determined during preimplantation embryo development by immunofluorescence staining from late 8 cell stage to the blastocyst stage. The E-cadherin expression was detected in all embryo stages that were examined (Figure 1-2). It has been known that E-cadherin is expressed and is present in the entire plasma membrane of 8 cell stage embryo until compaction (16). However, E-cadherin expression is restricted in basolateral cell-to-cell contact sites in late 8 cell stage, morula, E 3.5 and E 4.5 blastocyst stages (Figure 1-2). In late 8 cell stage embryo, there is no E-cadherin staining at the apical membrane of the peripheral blastomeres (Figure 1A).

We observed clear membrane staining on contact sites between blastomeres in morula stage embryos. Morula stage embryo consists of external (will generate TE cells) and internal (will generate ICM) cells. External blastomeres are positioned on the surface of the embryo, while internal blastomeres are completely surrounded by neighboring cells (17). We showed that E-cadherin protein is entirely localized around the internal blastomeres membrane and is also present in cell-cell contact sites of adjacent external blastomeres in morula (Figure 1B).

E-cadherin was detected at E 3.5 (expanding blastocyst) blastocysts as a membrane staining in cell-cell contact regions in TE cells while localized on the surface of ICM (Figure 1C). We analyzed the E-cadherin expression and distribution in E 4.5 blastocysts by applying double immunofluorescence staining using E-cadherin and actin proteins to visualize the cell borders. We observed membrane staining in cell-cell contacts of TE cells and intense membrane staining on the surface of PrE and Epi cells (Figure 2). 


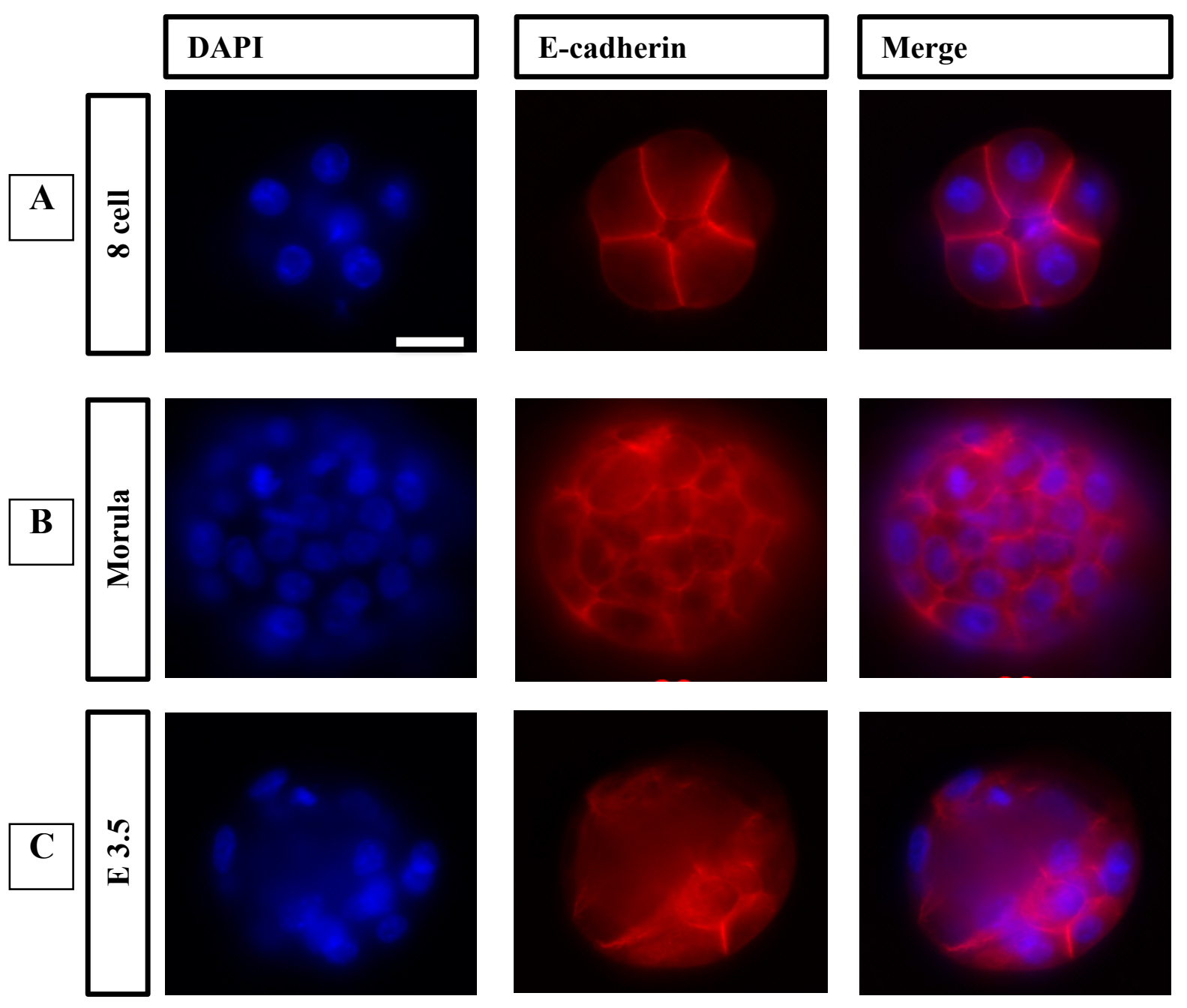

Figure 1: E-cadherin expression and distribution during preimplantation embryo development. [E-cadherin is expressed late 8 cell stage to blastocyst stage. E-cadherin is distributed in cell-cell junctions at late 8 cell (A), morula (B) and E3.5 (C) embryo stages. Fluorescence microscope images of the embryos which were stained with Ecadherin positive (red) and nuclei were stained with DAPI (blue). Scale bar represents $20 \mu \mathrm{m}$.]

Şekil 1: Preimplantasyon embriyo gelişimi sırasında E-kadherin ekspresyonu ve dağıllmı. [E-kadherin geç 8 hücre aşamasından blastosist aşamasına kadar eksprese edilmektedir. E-kadherin geç 8 hücre (A), morula (B) and E3.5 (C) embriyo aşamalarında hücre-hücre bağlantı alanlarında dağılım göstermektedir. Embriyoların floresan mikroskop görüntüleri E-kadherin pozitif (kırmızı) ve nukleus DAPI (mavi) ile boyanmış olan embriyoların floresan mikroskop

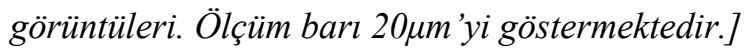



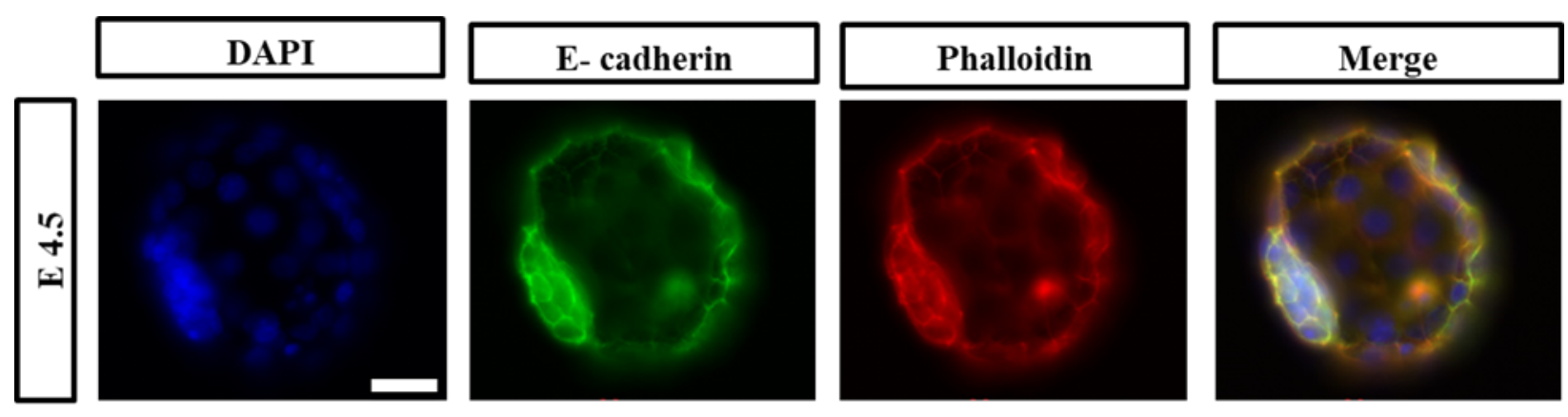

Figure 2: Double immunofluorescent staining of E-cadherin protein on E 4.5 blastocysts. [E-cadherin is localized at the cell-cell contacts of TE cells and on the surface of PrE and Epi cells. Fluorescence microscope images were stained with E-cadherin positive (green), F-actin-positive (red), and nuclei were stained with DAPI (blue). Scale bar represents $20 \mu \mathrm{m}$.

Şekil 2: E 4.5 blastosistler üzerinde E-kadherin proteinin immunfloresan boyaması. [E-kadherin, TE hücrelerinin hücre-hücre temas alanlarında, PrE ve Epi hücrelerinin yüzeyinde lokalizedir. Floresans mikroskop görüntüleri, E-kaderin pozitif (yeşil), aktin-pozitif (kırmızı) ile ve çekirdekler, DAPI (mavi) ile boyandı. Ölçüm barı $20 \mu m$ 'yi göstermektedir.]

\section{Discussion and Conclusion}

Cell adhesion is a critical process for early embryo development and implantation. We have investigated the expression and distribution of E-cadherin adhesion molecule, which is the major protein involved in the process of compaction and formation of adherens junctions during early embryo development (16). We have shown that Ecadherin protein is expressed throughout late 8 cell stage to fully expanded blastocyst. Indeed, it has been demonstrated that E-cadherin adhesion occurs during the 8 cell stage, and is present on the entire surface of the blastomeres plasma membrane. During compaction, E-cadherin mediated adhesion is redistributed and this molecule's presence is removed from apical membrane sites of the peripheral blastomeres $(10,16)$. Compatible with this study, we observed E-cadherin is localized at membrane domains between adjacent cells but not apical sites of the peripheral blastomeres. After compaction, we could not detect any staining on the outer surface of the embryo while E-cadherin became concentrated in cell-cell contact membrane regions. This shows us that E-cadherin plays a role on compaction process. It has been known that E-cadherin null embryos compact normally cause of the maternal E-cadherin provided stores but fail to form trophectoderm cell layer. E cadherin -/- embryos show morphological defects, which indicates that TE formation is affected by the absence of this protein. $(5,11,14)$. Studies also revealed that embryos lacking both maternal and zygotic E-cadherin fail to compact. Stephenson et al., determined lack of Ecadherin effect normal segregation of apical and basolateral region fail to form an organized outer polar epithelium which it will effects to form organized blastocyst afterwards $(1,15)$. In addition, E-cadherin null embryos could not hatch from zona pellucida, but hatching is an essential process for implantation of the embryo (14). We also observed membrane staining on cell-cell contact regions in E 3.5 and E 4.5 blastocyst stage, suggesting that this molecule has important roles on blastocyst formation. Studies also revealed that lack of E-cadherin expression causes defective adherens junctions which has essential roles on TE formation (9). E-cadherin adhesion contributes to trophectoderm epithelial differentiation and implantation process $(4,12)$.

Our results demonstrate and support the knowledge on expression and distribution of E-cadherin, which is the most important cell adhesion protein in preimplantation embryo development. We have shown that E-cadherin is expressed throughout the late 8 cell to fully expanded blastocysts. Our data suggested that E-cadherin has critical 
roles on morphogenetic events, including compaction and trophectoderm epithelium formation in early embryo development.

\section{References}

1. De Vries, WN, Evsikov AV, Haac BE, Fancher KS, Holbrook AE, Kemler R, Solter D, Knowles BB (2004): Maternal beta-catenin and Ecadherin in mouse development. Development, 131, 4435-4445.

2. Eckert JJ, Fleming TP (2008): Tight junction biogenesis during early development. Biochim Biophys Acta, 1778(3), 717-28.

3. Fleming TP, Sheth B, Fesenko I (2001): Cell adhesion in the preimplantation mammalian embryo and its role in trophectoderm differentiation and blastocyst morphogenesis. Front Biosci, 6, D1000-7.

4. Johnson MH, Maro B, Takeichi M (1986): The role of cell adhesion in the synchronisation and orientation of polarization in 8-cell mouse blastomeres. J Embryol Exp Morphol, 93, 239-255.

5. Larue L, Ohsugi M, Hirchenhain J, Kemler R (1994): Ecadherin null mutant embryos fail to form a trophectoderm epithelium. Proc. Natl Acad. Sci. USA, 91, 8263-8267.

6. Mihajlović AI, Bruce AW (2017): The first cell-fate decision of mouse preimplantation embryo development: integrating cell position and polarity. Open Biol, 7(11), pii: 170210. 70210.

7. Mutluay D (2016): Distribution of primitive endoderm and epiblast lineage specific factors in late stage blastocysts Slov Vet Res, 53 (4), 211-7

8. Mutluay D, Oner H (2017): The Abelson tyrosine kinase (c-Abl) localization in preimplantation mouse development. Rom J Morphol Embryol, 58, 1385-1391.

9. Niessen CM, Gottardi CJ (2008): Molecular components of the adherens junction. Biochim Biophys Acta, 1778(3), 562-71.

10. Ohsugi M, Hwang SY, Butz S, Knowles BB, Solter D, Kemler R (1996): Expression and cell membrane localization of catenins during mouse preimplantation development. Dev Dyn, 206(4), 391-402.

11. Ohsugi M, Larue L, Schwarz H, Kemler R (1997): Cell-junctional and cytoskeletal organization in mouse blastocysts lacking E-cadherin. Dev Biol, 185(2), 261-71.

12.Paria BC, Zhao X, Das SK, Dey SK, Yoshinaga K (1999): Zonula occludens-1 and E-cadherin are coordinately expressed in the mouse uterus with the initiation of implantation and decidualization. Dev Biol, 208(2), 488-501.

13. Piliszek A, Grabarek JB, Frankenberg SR, Plusa B (2016): Cell fate in animal and human blastocysts and the determination of viability. Mol Hum Reprod, 22(10), 681-690.

14. Riethmacher D, Brinkmann V, Birchmeier C (1995): A targeted mutation in the mouse E-cadherin gene results in defective preimplantation development. Proc. Natl Acad. Sci. USA, 92, 855-859.

15. Stephenson RO, Yamanaka Y, Rossant J (2010): Disorganized epithelial polarity and excess trophectoderm cell fate in preimplantation embryos lacking E-cadherin. Development, 137(20), 3383-91.

16. Vestweber D, Gossler A, Boller K, Kemler R (1987): Expression and distribution of cell adhesion molecule uvomorulin in mouse preimplantation embryos. Dev Biol, 124(2), 451-6.

17. Yamanaka Y, Ralston A, Stephenson RO, Rossant J (2006): Cell and molecular regulation of the mouse blastocyst. Dev Dyn. 235(9), 2301-14. 